\title{
Public transport in a small island of a developing country ${ }^{1,2}$
}

\author{
Transporte público em uma pequena ilha de um país em desenvolvimento
}

M. Shafiq-Ur Rahman

Associate professor, Department of Urban and Regional Planning, Jahangirnagar University, Dhaka - Bangladesh, email: shafiq_urp@yahoo.com

\begin{abstract}
This paper explores the existing forms of public transport system and their services as well as travel pattern of people in Siquijor Province, an island of the Philippines. Household questionnaire survey, interview of the passengers of various public transport modes at their stations, and a detailed participatory observation were conducted for the research. Bus, jeepney ${ }^{3}$, easyride ${ }^{4}$, tricycle $^{5}$, and habalhabal ${ }^{6}$ are the available public transport systems in the island. However, these services do not provide travel time, waiting time, availability or frequency, comfort, and safety that is required by passengers. Majority of the people mostly prefer the easyride for comfort and less waiting time whilst the bus for comfort. Considering the travel pattern, socioeconomic situation and topographic condition, the research tried to identify which form of public transport system would be appropriate for the island. It was found that bus is appropriate for longer trips while easyride for the inter-municipal trips and habalhabal for the trips in mountain areas.
\end{abstract}

Keywords: Barangay. Easyride. Habalhabal. Jeepney. Tricycle .

\section{Resumo}

Este artigo aborda os sistemas de transporte público, os serviços por eles ofertados e o padrão de deslocamento das pessoas na Província de Siquijor, uma ilha das Filipinas. Para o desenvolvimento desta pesquisa foram

\footnotetext{
1 The earlier version of this paper was presented in the 11th World Congress of Transport Research (WCTR) Conference, 24-28 June 2007, California, USA.

2 Acknowledgements: The author acknowledges the support from the provincial government of Siquijor in facilitating the field work activities for data collection. The role of German Technical Cooperation (GTZ) is also recognized for funding the travel expenses and a part of the data collection expenses. The author also thanks two anonymous reviewers for their valuable comments and suggestions, and Anzir Boodo (ITS, University of Leeds) for his generosity of English and grammar review.

${ }^{3}$ It comes from the word 'jeep'; passenger capacity mostly 24 people, while few with 19 or 21 or 33 people.

4 The smaller version of Jeepney (also called 'multi-cab') with passenger capacity of 12 people.

5 Motorcycle with an attached side-car and a wheel (three-wheeler), usually carry 4 to 6 people depending on size and design.

${ }^{6}$ Motorcycle for hire and operate as a public transport (or often like a taxi) mode, locally known as 'habalhabal'.
} 
utilizados formulário de pesquisa domiciliar, entrevistas com passageiros dos diversos meios de transporte público e uma minuciosa observação participativa. Ônibus, jeepney, easyride, triciclo e habalhabal são os sistemas de transporte público disponíveis na ilha. Contudo, estes serviços não proporcionam o tempo de viagem e espera, disponibilidade ou frequência, conforto e segurança demandados pelos passageiros. A maior parte das pessoas opta por se utilizar do easyride em função do conforto e do menor tempo de espera, ao passo que optam pelo ônibus em virtude do conforto oferecido. Considerando o padrão de viagens, situação socioeconômica e condições topográficas locais, este trabalho buscou identificar qual o sistema de transporte público mais apropriado para a ilha. Observou-se que o ônibus é o meio mais adequado para trajetos longos, enquanto o easyride se destaca nas viagens intermunicipais e o habalhabal nos trajetos em áreas montanhosas.

Palavras-chave: Barangay. Easyride. Habalhabal. Jeepney. Triciclo.

\section{Introduction}

The majority of people in the developing countries depend on affordable public transport services and non-motorized transport (NMT) for their travel (WORLD BANK, 1996). Lower-middle and lower income groups are especially heavily dependent on public transport (HOSSAIN, 2006). Dependence on public transport is mainly because of low ownership of personal vehicles. However, despite the importance of public transport, its services are often poor in developing countries (GAKENHEIMER, 1999). In urban areas, particularly in the major cities, often the demand for public transport far outstrips the supply. Consequently, as Gakenheimer (1999, p. 671) argued, the "mobility and accessibility are declining rapidly in most of the developing world". In rural areas, on the contrary, the situation might be different where low demand is hindering provision of frequent public transport services in a cost-effective manner.

A number of factors influence the shape of the public transport system of a city or region. For instance, according to Simpson (1994), the size of city, level of development or urbanization, travel pattern, and land use are the most significant factors influencing the public transport system. The length of journeys and nature of travel for the majority are important factors of determining travel means (BARWELL et al., 1985). Selecting travel mode of individual person's trips is influenced by internal and external factors (RAHMAN, 2007a). External factors are the attributes related to public transport service and their operation, which are often beyond the control of the user (i.e. service route, headway, fare, etc.), whilst internal factors include the intuitive decision making attributes of a user, on which he/she has control (i.e. income, family size, etc.). These factors that determine selection of a particular travel mode could be grouped as the characteristics of the 'trip', the 'trip maker', and the 'transport system' (RAHMAN, 2007a, 2008).

Nevertheless, travel demand is also determined by city population size, growth and structure, cultural and work habits, income, and urban spatial pattern (ALEPUZ, 1993; MITRIC, 1991; SHESKIN, 1991). Moreover, the city or region is often shaped by transport priorities (MARCHETTI, 1994), or vice-versa. For example, public transport in SouthEast Asian cities has been an important element of their respective urban systems (IWATA, 1995). Hence, a balanced provision of transport modes with a link to land use is a key to sustainability (NEWMAN; KENWORTHY, 1989). Thus, the provision of public transport for a city or region should be matched with the development level and travel pattern of the city.

The objective of this paper is to explore the existing public transport situation and the travel pattern in a small developing island of a developing country. Considering the travel pattern of people and their expectation regarding the public transport, the paper also tries determining the appropriate form of public transport for the island and guidelines to provide "suitable" public transport facilities. "Suitable" in this paper refers to efficient (in terms of travel time and waiting time) formal public transport services on fixed routes at scheduled times, which are available and affordable for the majority of people. The study confines itself only to land transport. 
Siquijor, an island province of the Central Visayas in the Philippines, is the study area for the research. Land area of the island is about $318 \mathrm{~km}^{2}$, mainly mountainous and rural in nature where rocky nonagricultural land and forest-cover are respectively $5 \%$ and $16 \%$ of the area (ECOLOGICAL PROFILE, 2003; PROVINCIAL PHYSICAL FRAMEWORK PLAN PPFP, 2004). Administratively the island is divided into six municipalities (Siquijor, Larena, Enrique Villanueva, Maria, Lazi, and San Juan) and $134 \mathrm{ba}$ rangay $^{7}$ (GEOGRAPHICAL ATLAS, 2000; PPFP, 2004). The island circumferential National Road, the major arterial, links all municipality centres. The built-up area of the island is only $2.5 \%$ of the total land and located along the National Road; and urban population is only $11 \%$ (PPFP, 2004). There were a total of 81,598 people in 2001 living in 17,775 households (BASELINE REPORT, 2002). The economy of the island is mostly based on agriculture. Average family income in year 2000 was Peso $^{8}$ (P) 79,119 where around 20\% families belong to the income bracket of P20,000-30,000 (ECOLOGICAL PROFILE, 2003; NATIONAL STATISTICS OFFICE - NSO, 2002).

\section{Research methods and data collection}

A comprehensive field survey of households was carried out for investigating the travel patterns of the people of Siquijor island. Due to resource constraints only 163 households ( $0.93 \%$ of the total) were selected using a Stratified Systematic Random Probability Sampling method and members of the selected households over 10 years of age were interviewed in 2007. A total of 395 individual respondents were found valid and considered for the analysis.

Besides the household interview, a detailed observation was made of the public transport systems and a participatory observation was performed to gain insights into the public transport services and supporting infrastructure facilities. Passengers waiting at the public transport terminal were also interviewed to assess service levels and 66 passengers using different modes were selected randomly from three major terminals (i.e. Siquijor, Larena, Lazi).
However, the research is mainly based on household information with additional information from the passenger interviews. Both questionnaires used had several sections to collect socio-economic and demographic information, details about each trip made on the previous day, and details on their usage of public transport (i.e. existing services, problems, their expectations, etc.). Besides these, the household survey questionnaire had a separate section of Stated Preference questions to explore preference among various public transport modes, as well as different scenarios of time and fare for travel on various modes. Discussions were also carried out with responsible agencies, political representatives, and transport associations, and relevant documents and project activities from the province have been reviewed and studied.

\section{Transport in Siquijor island}

Despite the very low household income there is a complete absence of cycle-rickshaw (called 'pedicab' in the Philippines) and bicycle in the Siquijor island. A city or region in the Philippines or in other countries having the socio-economic conditions similar to Siquijor has bicycles and cycle-rickshaws as common mode. Nevertheless, the hilly topography of Siquijor might be the reason for the absence of cycle-rickshaw and bicycle. Rahman (2008) also reported hilly topography as the cause of low bicycle and rickshaw use. The number of registered vehicles of the island was 5,266 in 2003, which is more than double that of in 1994 (only 1,923), with motorcycles and tricycles comprising over $80 \%$ of the vehicles (RAHMAN, 2007a). Provincial Profile (2000) reported that there were only 289 vehicles for hire, of which only 83 were utility vehicles and 200 tricycles, to serve around 81,500 inhabitants of the island.

The following sections briefly describe existing public transport systems on the island, people's travel patterns and trip characteristics, service levels and people's preferences of the existing public transport (attitude towards public transport), and finally the respondents' expectations about the services of various public transport modes.

\footnotetext{
7 Subdivision of the municipality (the smallest politico-administrative unit) in the Philippines.

8 Philippino Peso (P) 50 was equivalent to US\$1 in year 2000.
} 


\section{Public transport systems}

Existing public transport operating in Siquijor island can be grouped in two categories: fixed-route services (bus, jeepney and easyride), and door-todoor services (habalhabal and tricycle).

Buses and jeepneys operating in the island are similar in terms of their passenger capacity, services and fare. The size of buses operating is very small (capacity of 42 seats). Only four minibuses are operating on the Larena - Lazi (via Enrique Villanueva and Maria) route and daily provide around eight trips in each direction. Two existing jeepney routes are Siquijor - San Juan - Lazi and Larena - Enrique Villanueva - Maria - Lazi. Only 15 jeepneys are operating on the Siquijor - Lazi route while 24 on the Larena - Lazi route provide around 16 trips daily in each direction. Both the bus and jeepney stop frequently at any time and any place if a passenger wants to get off (alight) or on (board), which significantly affects the travel time and operation speed of vehicles. Average trip time for a distance of $30 \mathrm{~km}$ between Larena and Lazi (via Maria) is 90 minutes on bus and 90 to 120 minutes on jeepney. Though the operators of bus and jeepney had decided on a headway of 30 minutes for both routes and in each direction, in practice, drivers wait more time (making delay) in order to get more passengers. The fare is determined by the Land Transportation Franchise and Regulatory Board (LTFRB) on a per $\mathrm{km}$ rate. Standard fare for a jeepney from Siquijor Poblacion to San Juan Poblacion (about $12 \mathrm{~km}$ ) is P12 whilst for bus from Larena Poblacion to Enrique Villanueva Poblacion (about $13 \mathrm{~km}$ ) is P13. The fare is same for both jeepney and bus and their service level is also similar.

Easyride is faster than jeepney or bus and a common mode on the national road of Siquijor, Larena, Enrique Villanueva, and San Juan municipalities. The LARSIQSANMODE Association registered 97 easyrides for operating on the Larena - Siquijor San Juan route; however not all are operating now. Usually there are 40 trips in each direction every day between Siquijor and Larena by easyride, taking 30 to 40 minutes for a distance of $12 \mathrm{~km}$. Observation of easyrides at Siquijor terminal gave an average headway of 35 minutes. Despite the permission for operating easyride only up to San Juan Poblacion; sometimes they go up to barangay Catulayan, $8 \mathrm{~km}$ further ahead on the border of San Juan (Figure 1). On the other hand, around 25 easyrides are operating on the Larena - Enrique Villanueva route and every day provide around 20 trips in each direction with an average headway of 18 minutes. However, more frequent service (i.e. headway less than 10 minutes) on easyrides is available in the morning, particularly between 8:00 am and 9:00 am. This is due to heavy demand created by the large number of students travelling to their college in Larena. Despite the permission to operate up to Enrique Villanueva Poblacion, as with the other route, they operate $6 \mathrm{~km}$ ahead up to barangay Lotloton. Between Larena and Enrique Villanueva Poblacion, a distance of $12 \mathrm{~km}$, easyride takes around 30-40 minutes with a fare of P8. Usually easyrides are available between 6:00 am and 6:00 pm and there is no specific time-schedule or stopping points.

Tricycle is suitable for short-distance trips in less hilly areas and provides door-to-door services between 6:00 am and 6:00 pm. However, sometimes a few of them operate on certain fixed routes. About 302 tricycles are operating on the island and play a major role in transport in and around Siquijor Poblacion and Larena Poblacion (RAHMAN, 2008). Because of the hilly topography, very few tricycles are operating in the municipality of Enrique Villanueva, Maria, and Lazi. Fares for tricycles are determined by the local government unit (LGU) on a $\mathrm{km}$ rate basis. However, the driver of a tricycle usually determines the fare depending on the number of passengers riding - higher for single passengers while less if shared with others.

Habalhabal is the only mode which is accessible in mountainous areas where other modes (i.e. bus, jeepney, easyride, tricycle) are not accessible, and in each and every part of the island even where other modes are also operating. There are about 674 habalhabal in the island (RAHMAN, 2007a), available for a ride at any time; however, a very high fare (depending on bargain) is applied after 6:00 pm. Even though fares of habalhabal are not fixed, the drivers almost always follow a similar fare structure. The per $\mathrm{km}$ fare is higher for longer distance trips compared with shorter ones. Interestingly, the fare for the same distance uphill is more than downhill; e.g. Poblacion Siquijor to Ponong is P20 while in the reverse direction it is P15. Fares on habalhabal are much higher compared with other modes. For 


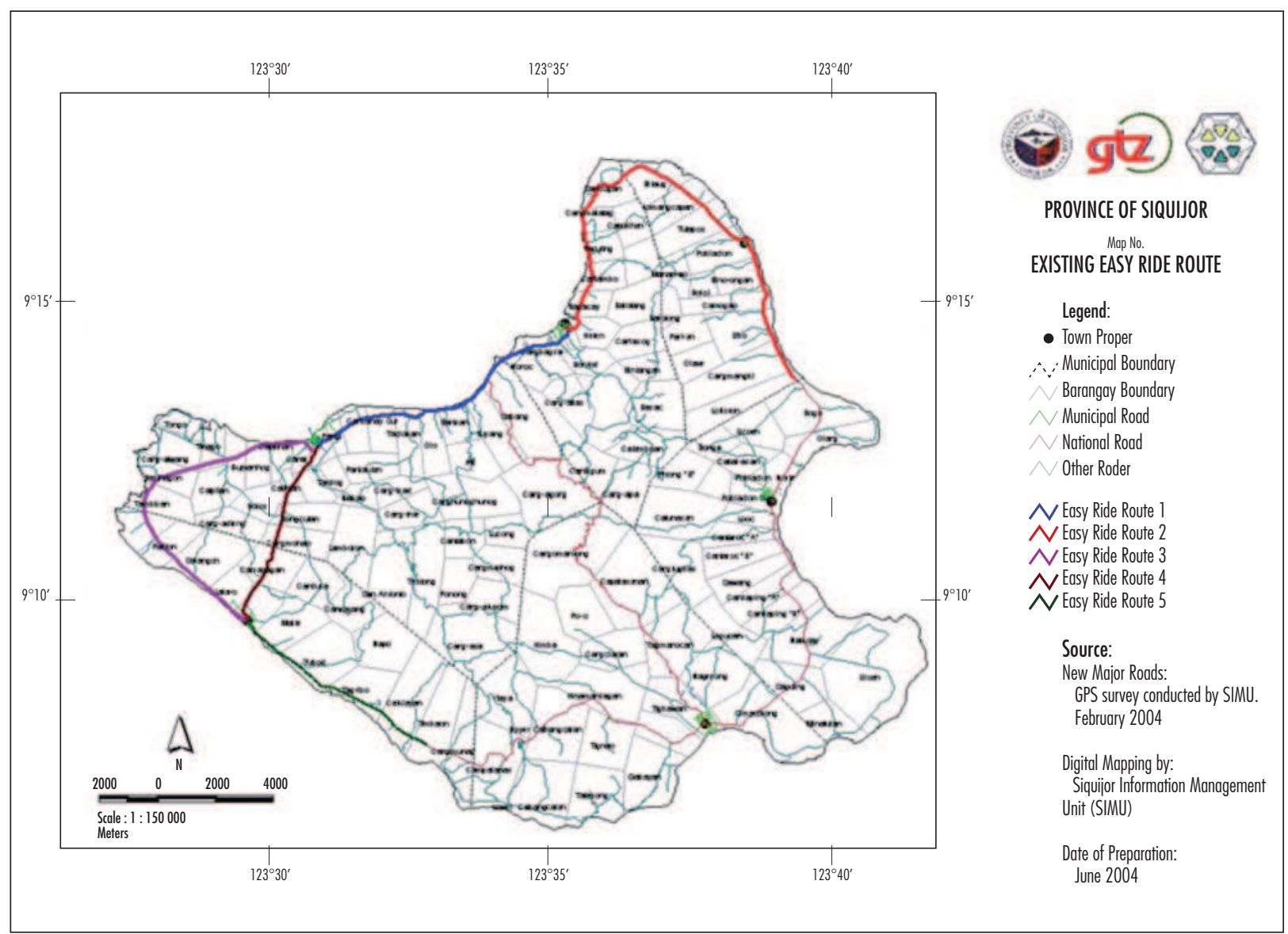

Figure 1 - Road network and the existing route of easyride service

SOUICE: SIQUIJOR INTEGRATED RESOURCE MANAGEMENT PROJECT - SIRMAP, 2007.

example, Siquijor to Larena is P30 on habalhabal where it is only P8 on jeepney or easyride.

\section{Travel pattern of the respondents}

Socio-economic and demographic profile of the sample population are almost similar to the secondary information of the island, which reveals that the sample is representative of the whole population. Only $42 \%$ of the respondents have family owned vehicle, mostly motorcycles $(70 \%)$ while a few have tricycles (10\%). Average monthly household expenditure for transport in Siquijor is P535 whilst $12 \%$ spend less than P50 and $10 \%$ spend over P1,000.

Around $38 \%$ of the household respondents usually make between five and ten trips per week, about $22 \%$ make two to four trips per week, and another $22 \%$ make only one trip per week while the remaining respondents travel very rarely (only a few trips in a month). The majority (58\%) of passengers interviewed also gave a weekly trip frequency of up to four. It was found that more trips are made by higher income groups or people having a household vehicle. This observation is very common and in line with transport literature. However, in some cases (depending on socio-economic condition and city size or pattern), the obvious observation of transport literature is not available in the developing world. For instance, vehicle owners do not make more trips compared with others and the frequency of trip for both higher-income group and poor-income group is almost similar in the central area of Khulna city in Bangladesh (RAHMAN, 2003). There also exist significant differences in trip frequency with occupation in Siquijor island - student, teacher, and government employees have higher 
trip frequency; while housewives, business people, and farmers have lower frequency of trips.

Multiple or connected trips on the island are very few, only $6 \%$ of the total. Moreover, the residence as the origin of the first trip and the destination of the second trip (in more than $92 \%$ of cases), indicates that the trips are "home-bound". The major destinations are commercial centres (24\%) and educational centres (18\%), and subsequently the major trip purposes are work (23\%), shopping $(20 \%)$ and education $(14 \%)$. The majority of trips originate from home and start between 7:00 am and 10:00 am whilst the return trips to home are around noon and between 4:00 pm and 5:00 pm. Though average trip distance is $5.36 \mathrm{~km}$, almost $35 \%$ trips are shorter than $1 \mathrm{~km}$ and only $4 \%$ are longer than $15 \mathrm{~km}$.

Modal share of trips reveal that 33\% are walked, $23 \%$ by private vehicles (i.e. motorcycle, car, van, etc.), and $44 \%$ on public transport modes (14\% habalhabal, $15 \%$ tricycle, $7 \%$ easyride, $7 \%$ jeepney, and only $1 \%$ bus). The high portion of walking trips in Siquijor island is because almost half of the respondents (42\%) mentioned that usually they walk if there is not any available public transport; as noted earlier that $35 \%$ of trips are shorter than $1 \mathrm{~km}$ which could be travelled easily by walking.

The respondents had been asked the reason for using their travel mode and almost half of them mentioned either 'unavailability of any other mode' or 'convenient'. However, the reasons are diverse; for instance, 'short distance', 'have no money' or 'no transport available' are given by pedestrians, whilst 'convenient' or 'have family, hence cheaper' are given for private vehicles. On the other hand, habalhabal users mostly mentioned 'unavailability of any other mode' or 'go[es] close to destination' or 'less waiting time' while tricycle users mentioned 'less waiting time'. In contrast, 'safety' or 'less travel time' or 'less waiting time' for easyride; 'cheaper' or 'comfort' for jeepney; and 'comfort' or 'safety' for bus have been reported by the majority of passengers. Whatever, a Chi-Square test showed a significant difference between gender and travel mode among the tricycle, easyride, and jeepney users the number of women is more than men, whilst reverse is true for habalhabal passengers and pedestrians.

\section{Trip characteristics}

Each individual trip had been considered in the analysis of trip characteristics and there were a total of 904 trips. Trip distance reveals that the public transport modes dominate for distances between 1 and $15 \mathrm{~km}$ (Figure 2). Surprisingly, trips on private vehicles have been found for very short distances such as less than $0.2 \mathrm{~km}$ (though of course in very few cases). However, the number of trips on private vehicles increases if the trip distance is longer. For instance, the number of trips by private vehicle is more than that of public transport when the distance is over $15 \mathrm{~km}$. The number of trips on public transport increases over walking if the distance is more than $1 \mathrm{~km}$ and that trend continues. Though the walking limit is $5 \mathrm{~km}$, almost $80 \%$ of walking trips are less than $2 \mathrm{~km}$ and the percentage of walking trips decreases dramatically if the distance is more than 1 km (Figure 3).

Trips on public transport modes reveal that all the trips within $0.5 \mathrm{~km}$ are made only on habalhabal or tricycle; and there is no trip on jeepney or bus for a distance of less than $2 \mathrm{~km}$ (Figure 4). The trips between 10 and $15 \mathrm{~km}$ distance are mostly made on easyride. Even though habalhabal trips are available both for short and long distance, the majority (88\%) are between 1 and $10 \mathrm{~km}$. Despite the majority of tricycle trips (41\%) being less than $1 \mathrm{~km}$, the number of walking trips is still much higher than tricycle over this distance range.

No significant relationship was found between income and choice of public transport mode in Siquijor island. However, most of the students ride tricycles or easyrides while very few of them walk or use buses. This indicates that students may prefer faster transport with less waiting time. Almost $56 \%$ of trip makers do not need to wait for travel as they are either walking or using a private vehicle. The waiting time for public transport was found to be higher for the trips with longer travel time; however, a few trips over shorter distances involved a long waiting time. For instance, few passengers reported that they had to wait 40 to 60 minutes or even 60 to 120 minutes for a trip of less than $5 \mathrm{~km}$ or a journey of 20 to 40 minutes or even 5 to 20 minutes. 


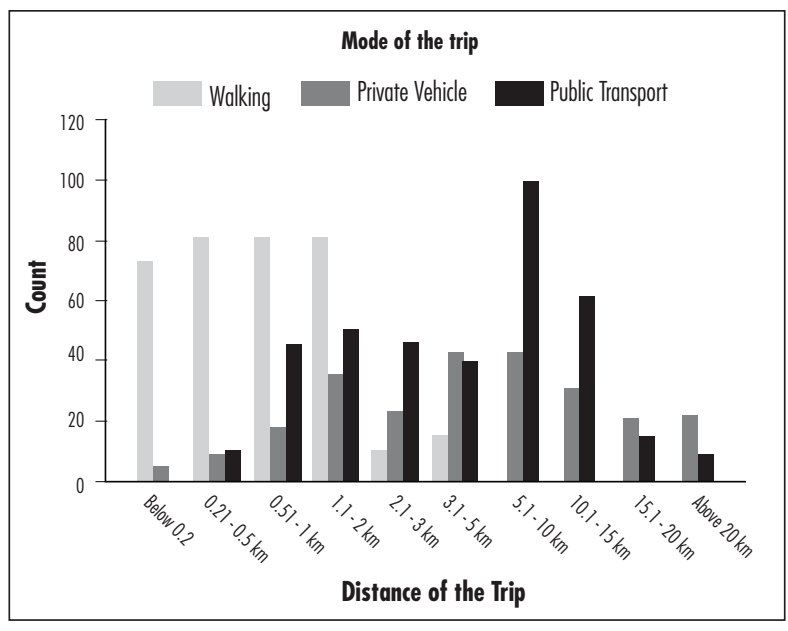

Figure 2 - Frequency of trip on different mode and distance Source: RAHMAN, 2007b.

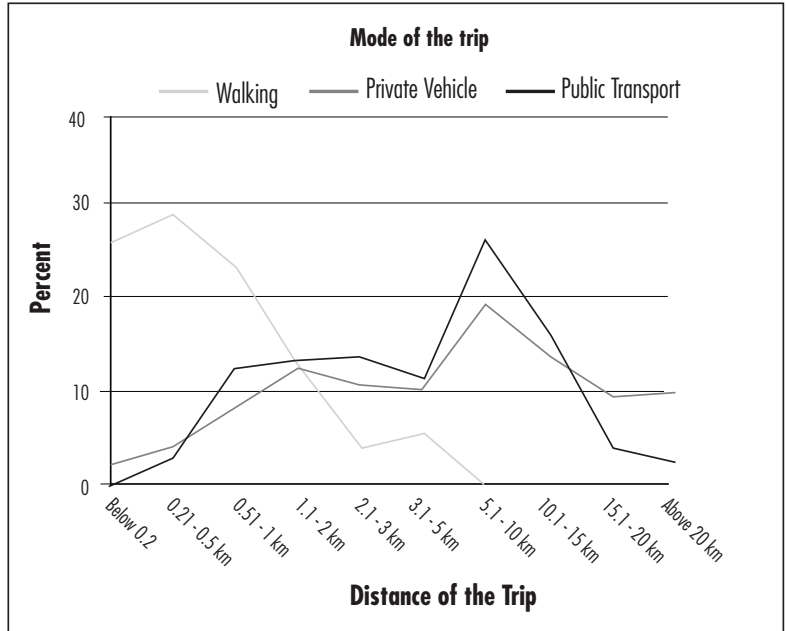

Figure 3 - Percentage of Trips for Different Distance

Source: RAHMAN, 2007b.

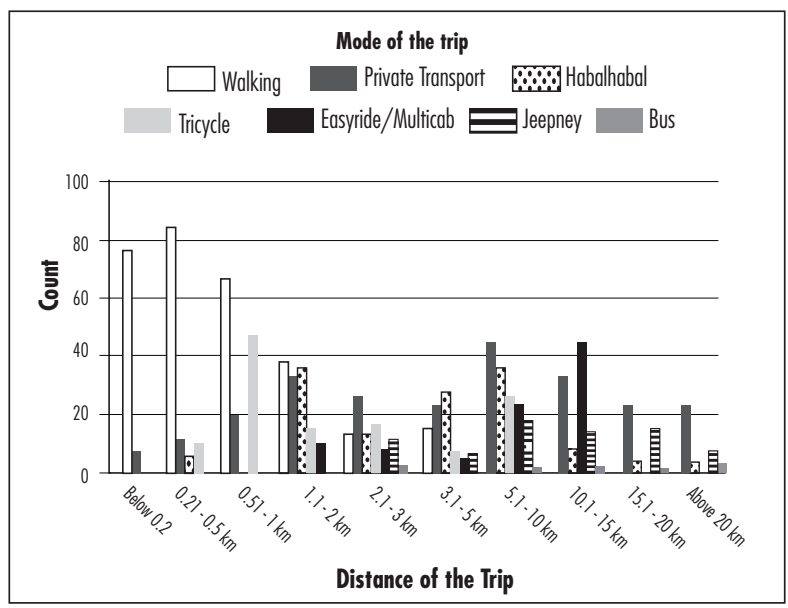

Figure 4 - Number of trips on various public transport modes for different distance Source: RAHMAN, 2007b.
Surprisingly, it was found that a few passengers using habalhabal, tricycle and easyride do not pay the fare as it is their relative or friend's vehicle. Among the public transport modes, majority of the trips costs are below P10. Fares for the majority of tricycle trips are below P5, while for easyride or jeepney trips are generally in the P6 to P10 range. Very few trips cost more than P20, these were by habalhabal or jeepney.

Public transport: service level, passengers' usage and preference

Around $70 \%$ of the respondents in Siquijor island use public transport. The remainder never use public transport because they either walk or use personal (family owned or office) vehicles. In contrast, about $30 \%$ users of the public transport have family owned vehicle.

Habalhabal users mostly live in mountainous areas or in barangays with no national or provincial road access. However, most of them reported that habalhabal is often available at their home or work place within five minutes, though some also mentioned having to wait 20 to 40 minutes or sometimes 40 to 60 minutes. More than half (53\%) of the habalhabal users use it either once or two to four times per week whilst a significant portion (33\%) use it only one to two times per month. This low frequency of trips on habalhabal is because they also use other modes. The majority of habalhabal users are satisfied with the availability and comfort, but almost half of them are worried about safety. Surprisingly, almost three-quarters of users mentioned that they would not use it if there was a jeepney or easyride or bus service available.

Similarly, the frequency of tricycle usage is either once or 2 to 4 times per week and it is often available at home or the work place. However, onequarter of them mentioned that they have to either walk or ride habalhabal for a certain distance (ranging from 1 to $8 \mathrm{~km}$ ) towards the nearby main road and wait to catch a tricycle. The majority of tricycle users have reported waiting times of less than 20 minutes, and for almost $90 \%$ of trips, the cost is less than P5 (due to the short distance travelled). Most of the tricycle users are "somehow satisfied" about its availability and comfort. 
Easyride users mostly live in Poblacion or coastal areas in the municipality of Siquijor, Larena, San Juan and Enrique Villanueva. Frequency of easyride usage is either once a week or one to two times per month for most of the users. Though it is available at home or work for a few, about two-thirds have to walk or ride habalhabal (for various distances) towards the nearest main road or terminal to catch the easyride. Despite a waiting time reported by more than $90 \%$ of either five to 20 minutes or 20 to 40 minutes, almost all the respondents are 'very happy' about the comfort, safety, and availability of easyride.

Jeepney users are spread throughout the island and their frequency of usage is similar to users of easyride - once per week or one to two times per month for the majority. Two-thirds of the jeepney users have to go to the nearby main road or terminal to catch a jeepney, and mostly they walk. Often they have to wait 40 to 60 minutes and are consequently 'not happy' about availability. Nevertheless, more than $90 \%$ of the passengers are very happy about the safety and comfort of jeepney.

Bus passengers mostly live in the municipalities of Larena, Enrique Villanueva, Maria, and Lazi; and the frequency of usage is very rare - only one or two times per month for the majority. More than $75 \%$ of bus passengers also have to go towards the main road or terminal to catch one and have to wait 40 to $60 \mathrm{~min}$ utes, similar to jeepney passengers. As with jeepney, the majority of bus passengers are very happy about safety and comfort despite its poor availability.

To explore the most preferable public transport mode for the island, the respondents were asked which mode they like most. Among the available public transport, the most preferable mode was habalhabal (32\%) followed by easyride (30\%) and tricycle (17\%). However, it should be noted that habalhabal has been reported mostly by the people who have no other mode available for travel. For this reason, of those who mentioned habalhabal as the most preferable mode, more than half of them reported that they would not use it if there were jeepney, easyride or bus services available.

Hence, it is important to look at the causes behind the preferences (Table 1). The majority mentioned 'availability' and 'comfort' while the rest also pointed to 'safety', 'less travel time', 'less waiting time' and 'cheaper' as reasons. To some extent, this is similar to the study findings of Andaleeb (2007), who found 'comfort level' and 'waiting facilities' have significant effects on bus passengers' satisfaction in developing

Table 1 - Most preferable public transport mode and the reason for preference

\begin{tabular}{|c|c|c|c|c|c|c|}
\hline \multirow{2}{*}{ Reason } & \multicolumn{5}{|c|}{ Best preference } & \multirow[b]{2}{*}{ Total } \\
\hline & Habalhabal & Tricycle & Easyride & Jeepney & Bus & \\
\hline Cheaper & & & 4 & 20 & 4 & 28 \\
\hline Only available & 54 & 14 & 5 & 6 & & 79 \\
\hline Nearby available & 2 & 1 & & & & 3 \\
\hline Comfortable & 2 & 4 & 46 & 6 & 12 & 70 \\
\hline Safe/Less accident & & 1 & 8 & 3 & 1 & 13 \\
\hline Go all places (close to destination) & 13 & 16 & 1 & & & 30 \\
\hline Fast/Less travel time & 15 & & 7 & & 1 & 23 \\
\hline Less waiting time & 2 & 4 & 10 & & & 16 \\
\hline Own/Family have & 1 & 1 & & & & 2 \\
\hline More space/Carry goods & & 2 & & 2 & 1 & 5 \\
\hline Convenient & 1 & 5 & 1 & & & 7 \\
\hline More people (interaction) & & & 1 & 1 & & 2 \\
\hline Total & 90 & 48 & 83 & 38 & 19 & 278 \\
\hline
\end{tabular}

Source: RAHMAN, 2007a.

Note: Value in the cells represents the frequency of the respondents. Empty cell means no respondent mentioned about that. 
countries. It is obvious that the reason for preference in Siquijor island does vary greatly between modes. For instance, those who have reported easyride as their most preferred mostly choose it for 'comfort' or 'less waiting time' or 'less travel time'. On the other hand, 'go close to destination' was the most important for tricycle whilst either 'cheaper' or 'comfort' for both jeepney and bus were the most common reasons in those cases. However, it should be noted that 'comfort' here does not mean that jeepney or bus services are very comfortable; rather this is somehow better compared with other modes available in Siquijor island.

Only 227 respondents gave their second preference (which means they reported using more than one mode). In those, bus was preferred by the majority followed by easyride and jeepney. In most cases the respondents reported as their most preferable mode the one they use most often.

\section{Expectations about public transport service}

The major problems of public transport in Siquijor are the absence of well-specified routes and stopping points, availability of services in certain areas, long waiting times, lack of comfort and overcrowding; these are, however, common issues in developing countries. However, the majority of the respondents expect public transport to have well-specified route and stopping points, more coverage, and scheduled service.

The respondents had been asked from a given set of public transport modes (if those are available) which they would select for their trip. Among the jeepney and easyride users, more than half of them (55\%) would choose easyride because of comfort, speed and reduced waiting time; however, more than a quarter would prefer jeepney (being cheaper) whilst the remainder considered both as equivalent. Among tricycle and habalhabal users, the majority would prefer tricycle because of comfort and safety. On the other hand, if both are available, the majority would prefer easyride over tricycle for comfort and speed while a few would choose tricycle for less waiting time. Again, almost $70 \%$ of the respondents would prefer bus over jeepney due to comfort and safety. This discussion of preference could be summarised as in Table 2 .

Table 2 - Preference of Public Transport Modes with Respect to Different Factors

\begin{tabular}{|c|c|c|c|c|c|c|c|c|c|c|}
\hline \multicolumn{11}{|c|}{ Preference of the Travel Modes } \\
\hline Factors & & Highest & & & & & & & & Lowest \\
\hline Fare rate & : & Habalhabal & $>$ & Tricycle & $>$ & Easyride & $>$ & Bus & $>$ & Jeepney \\
\hline Comfort & : & Bus & $>$ & Easyride & $>$ & Jeepney & $>$ & Tricycle & $>$ & Habalhabal \\
\hline Safe & : & Bus & $>$ & Jeepney & $>$ & Easyride & $>$ & Tricycle & $>$ & Habalhabal \\
\hline $\begin{array}{l}\text { Go all places or } \\
\text { go close to destination }\end{array}$ & : & Habalhabal & $>$ & Tricycle & $>$ & $\begin{array}{l}\text { Easyride } \\
\text { Jeepney } \\
\text { Bus }\end{array}$ & & & & \\
\hline Fast/ less travel time & : & Habalhabal & $>$ & Easyride & $>$ & Bus & $>$ & Jeepney & $>$ & Tricycle \\
\hline Waiting time & : & Bus & $>$ & Jeepney & $>$ & Easyride & $>$ & Tricycle & $>$ & Habalhabal \\
\hline $\begin{array}{l}\text { More space or } \\
\text { easy to carry goods }\end{array}$ & : & $\begin{array}{l}\text { Bus } \\
\text { Jeepney }\end{array}$ & $>$ & Easyride & $>$ & Tricycle & $>$ & Habalhabal & & \\
\hline Convenient & : & Easyride & $>$ & Habalhabal & $>$ & $\begin{array}{l}\text { Jeepney } \\
\text { Tricycle }\end{array}$ & & & & \\
\hline Bad odor and noise & & $\begin{array}{l}\text { Jeepney } \\
\text { Tricycle }\end{array}$ & $>$ & Easyride & & & & & & \\
\hline
\end{tabular}

Source: RAHMAN, 2007a. 
From the above discussion of preference, it could be seen that people of Siquijor seem to prefer largeoccupancy vehicles and timetabled services for long-haul journeys. Moreover, the majority of them want more specific routes and timetables for bus, jeepney and easyride, and also specific routes for easyride. However, transportation planning literature implies that actual behaviour is one-quarter of the expressed behavioural intent (SHESKIN, 1991). Thus, it would be much more appropriate if only the passengers of a particular mode are considered for exploring their expectations about public transport. Because of poor availability and consequently long waiting time; the majority of easyride, jeepney and bus users want more specific routes, schedule and stopping places for the respective modes (almost $90 \%$ for easyride users). Nevertheless, a few of the respondents think that specified timetables for easyride, jeepney and bus may increase waiting time, so do not want them, and many do not even want specified stopping places for any mode because they want public transport at their doorsteps. Surprisingly, one-third of habalhabal users want more specified routes while more than half of the tricycle users want specified route and more coverage. This indicates the users of a particular mode mainly want improvements in what they are already using. The majority of the respondents mentioned a desire for passenger shelters with seating facilities at terminals.

\section{Conclusions and recommendations}

Even though the majority of people on Siquijor island use public transport, the number of public transport vehicles is less than $5 \%$ of the total number of vehicles registered (RAHMAN, 2007a). This situation is similar to other developing countries. Most people are dependent on public transport for their travel but its availability is limited and service can be very poor (GAKENHEIMER, 1999). Besides, there is a complete absence of public transport support infrastructure.

Almost half of the people in Siquijor make less than four trips per week and are mostly spend less than P10 per trip. Availability of bus and jeepney is poor while habalhabal is not considered safe for travel. Easyride and bus are the most preferable modes of public transport, though most people prefer comfortable and cheaper modes that go close to their destinations.

The study found that women do not like habalhabal but prefer tricycle whilst men prefer habalhabal. The study concludes that the people of Siquijor are biased - they prefer and want improvement in the mode which they use most often. However, there are also some other factors like availability, cost, comfort etc. involved in this preference.

Policy guidelines should be directed towards providing comfortable, cheap, and fast public transport to all with less waiting time to address the preference and expectations of the majority. Around $35 \%$ of the household respondents use habalhabal and among the public transport trips its contribution is also $35 \%$. Without habalhabal, walking is the only available mode of travel in mountainous areas for those who have no family owned vehicle. Even though playing a crucial role of transport, habalhabal is illegal (colorum). However, due to identification and implementation problems, it may not be possible to restrict it at the moment (RAHMAN, 2007a). If somehow these problems could be solved and the habalhabal becomes restricted, some people will lose their work and earnings while people living in mountainous areas, without a family owned vehicle, will have to walk even $15 \mathrm{~km}$ to go the nearest market to purchase food.

Transportation systems, as Macario (2001) suggests, need to establish the trade-offs between various dimensions according to the socio-economic and cultural reality of each specific environment. Thus, considering the socio-economic condition and topographical features, this study recommends the legalisation of habalhabal at local level (Municipal Government) as with tricycles. The president of the habalhabal association in Siquijor, Larena, Maria, and Lazi also sought its legalisation. Local Government Units (LGUs) are aware about the local issues and concerns, and each LGU has their own statutory power to enact transport related rules. Legalizing habalhabal could be done by strengthening the existing drivers' association and providing logistical support from the LGU if licencing of individual operators is transferred from LGU through the association. A fee for registration could 
be imposed; but this should be kept low, otherwise habalhabal drivers may try to avoid registering.

Given the very specific nature of Siquijor, this study recommends operating bus or jeepney in the national road circling the island, easyride only on inter-municipal corridors, tricycle only within municipalities' roads, and habalhabal only in mountainous areas. However, if the road network and condition is improved in the future, habalhabal might be replaced by High Occupancy Vehicles (HOVs). The existing minibus service of Larena Lazi route could be expanded to the whole circumferential national road after a detailed financial feasibility study.

Easyride should operate on specified routes only. Subject to further research on cost-benefit analysis, easyride service could be expanded on some major roads like Larena - Basac - Maria; and in other municipalities for inter-municipal connections. Through the tricycle association, it is possible to assign some tricycle routes connecting the municipal centre to barangay or growth centres. The study suggests allowing habalhabal operation only in mountainous areas but restricting them in the areas where other transport modes are available. This may give a two-way benefit: more habalhabal will be available in hilly areas and the conflict of interest with other transport mode operators will be minimised. However, this should be done through the drivers' association of various modes with mutual bilateral understanding.

The study recommends following specified times of 20 minutes interval for easyride services. The study further suggests that bus, jeepney, and easyride should follow specified time schedules. However, if the vehicle is fully occupied before the specified time, it may depart the terminal immediately. Moreover, the frequent stopping of bus, jeepney, and easyride should be reduced to be in specified locations only. The minimum spacing of stops could be $2 \mathrm{~km}$ for bus and jeepney and $1 \mathrm{~km}$ for easyride, whereas trips of less than $1 \mathrm{~km}$ could be served by tricycle or walking.

Public transport of Siquijor operates privately and individually without any coordination among operators of different modes and even within the mode. If a mixture of different modes offer shortdistance transport, their interrelationships are crucial for service quality (PUCHER; KURTH, 1996;
ROSCHLAU, 1985). This paper recommends forming an association for each transport mode to manage their operations, as well as an integrated transport association between different modes (association of the associations). LTO officials should also be incorporated in this committee where LGU or PPO (provincial planning office) could play the role of facilitator or coordinator. This integrated public transport association will be the apex body for decision-making in the province.

The study also recommends public transport management and provision of some public transport-supporting infrastructure, i.e. at least one waiting shelter with seating facilities at each municipal terminal so that passengers could rest while waiting. Avenues for further research could include the operation of different public transport modes or preparing a logistic regression model of how people will choose mode.

\section{References}

ANDALEEB, S. S. Reforming inner-city bus transportation in a developing country. Journal of Public Transportation, v. 1, n. 1, p. 1-24, 2007.

ALEPUZ, M. Bicycles overtakes buses travel in Havana. The Urban Age, v. 2, n. 1, 1993.

BARWELL, I. et al. Rural transport in developing countries. London: International Technology Publications, 1985.

BASELINE REPORT. Baseline study report of Siquijor province. Siquijor: Siquijor Integrated Resource Management Project - SIRMAP, 2002.

ECOLOGICAL PROFILE. Ecological profile of Siquijor province. Siquijor: [s.n.], 2003.

GEOGRAPHICAL ATLAS. Geographic atlas of Siquijor. Provincial Government of Siquijor, 2000.

GAKENHEIMER, R. Urban mobility in the developing world. Transportation Research Part A - Policy \& Practice, v. 33, n. 7/8, p. 671-689, 1999.

HOSSAIN, M. The issues and realities of BRT planning initiatives in developing Asian cities. Journal of Public Transportation, BRT special edition, p. 69-87, 2006. 
IWATA, S. Development and sustainability of public transportation in Southeast Asian cities. Journal of the Eastern Asian Society for Transportation Studies (EASTS), v. 1, n. 2, p. 547-564, 1995.

MACARIO, R. Upgrading quality in urban mobility systems. Managing Service Quality, v. 11, n. 2-6, p. S747-S753, 2001.

MARCHETTI, C. Anthropological invariants in travel behaviour. Technical Forecasting and Social Change, v. 47, n. 1, p. 75-78, 1994.

MITRIC, S. Crisis and recovery: urban public transport. In: NATIONAL RESEARCH COUNCIL - TRANSPORTATION RESEARCH BOARD. Public transit research: management and planning. Washington: Transport Research Board, 1991.

NEWMAN, P. W. G.; KENWORTHY, J. R. Cities and automobile dependence. Aldershot: Gower, 1989.

NATIONAL STATISTICS OFFICE - NSO. Census of population and housing: Siquijor. Report No.3-75G: socio-economic and demographic characteristics. Manila: National Statistics Office, 2002.

PROVINCIAL PROFILE. Region VII: Central Visayas. Manila: Siquijor Province, 2000.

PROVINCIAL PHYSICAL FRAMEWORK PLAN - PPFP. Provincial physical framework plan (PPFP) of Siquijor. Siquijor: Provincial Government of Siquijor, 2004.

PUCHER, J.; KURTH, S. Verkehrsverbund: the success of regional public transport in Germany, Austria and Switzerland. Transport Policy, v. 2, n. 4, p. 279-291, 1996.

RAHMAN, M. S. U. Factors influencing traffic generation in the town centre of a regional city: a study on Khulna metropolis of Bangladesh. Jahangirnagar Planning Review, v. 1, p. 51-63, 2003.
RAHMAN, M. S. U. Determining appropriate public transport system given the level of development/urbanization: the case of Siquijor province. In: WORLD CONGRESS OF TRANSPORT RESEARCH - WCTR, 11., 2007. Proceedings... California: WCTR, 2007a. (Paper ID 131).

RAHMAN, M. S. U. Household survey. Siquijor, 2007b. Unpublished survey.

RAHMAN, M. S. U. Appropriate public transport system for better environment. In: GUPTA, K. R. et al. (Ed.). Global environment problems and policies. New Delhi: Atlantic Publishers and Distributors, v. 3, p. 96$107,2008$.

ROSCHLAU, M. W. Public transportation in the provinces: a study of innovation, diffusion and conflict in the Philippines. Canberra. 1985. Thesis (Doctorate in Transportation Geography), Australian National University, 1985

SHESKIN, I. M. Relationship between surveyed behavioural intent and actual behaviour In: NATIONAL RESEARCH COUNCIL - TRANSPORTATION RESEARCH BOARD. Public transport research: management and planning. Washington, D. C.: Transportation Research Board, 1991.

SIMPSON, B. J. Urban public transport today. London: E \& FN Spoon, 1994.

SIQUIJOR INTEGRATED RESOURCE MANAGEMENT PROJECT - SIRMAP. Road network and the existing route of easyride service. Siquijor: Provincial Government of Siquijor, 2007.

WORLD BANK. Development in practice: sustainable transport. Wahsington, D.C.: The World Bank, 1996.

Received: 04/05/2011 Recebido: 05/04/2011

Approved: $11 / 22 / 2011$ Aprovado: 22/11/2011 